\title{
O PRINCÍPIO DA PROLIFERAÇÃO CONTRA O ARGUMENTO DA ELIMINAÇÃO. O CASO DAS CIÊNCIAS SOCIAIS
}

\author{
The Principle of Proliferation against the argument by \\ elimination. The case of the social sciences \\ El Principio de Proliferación contra el argumento de la \\ eliminación. El caso de las ciências sociales
}

Alberto Oliva ${ }^{1}$
Universidade Federal do Rio de Janeiro, Rio de Janeiro, RJ, Brasil.

\section{Resumo}

Com o objetivo de criticar a defesa do Princípio da Proliferação feita por Feyerabend, avaliaremos em que medida as ciências sociais se beneficiam do fato de abrigarem uma considerável diversidade de teorias e metodologias. A despeito de ser uma realidade nas disciplinas sociais, a proliferação nunca é vista como capaz de incrementar a testagem de uma teoria contrastando-a com alternativas. Os cientistas sociais descreem que existam falsificadores potenciais de uma teoria que só teorias diferentes se revelam aptas a localizar. Tendo de conviver com a diversidade explicativa, as ciências sociais contrariam a tese feyerabendiana de que, em virtude de cada teoria ter acesso apenas a determinados fatos, a desconsideração de alteridades deixa na penumbra fatos localizados por elas. A multiplicação de ópticas tem sido combatida recorrendo-se ao argumento da eliminação por meio do qual as teorias sociais já formuladas são escrutinadas com o objetivo de se demonstrar suas falhas e apontar uma alternativa

\footnotetext{
1 Doutor em Filosofia (UFRJ) - Rio de Janeiro. Professor Titular do Depto.de Filosofia da UFRJ. Pesquisador 1-C do CNPq. - Brasil. ORCID: http://orcid.org/oooo-0001-6476-3195. E-mail: aloliva@uol.com.br
} 
como a única aceitável por ser a sobrevivente aos crivos empíricos. Apontaremos as razões pelas quais se tem recorrido ao argumento da eliminação contra a duplicação e a proliferação de teorias nas disciplinas sociais. A proliferação carece das vantagens epistêmicas que Ihe atribui Feyerabend tendo em vista que as teorias sociais não testam umas às outras. Mesmo que possível, a testagem recíproca revela-se inútil porque se há fatos só localizáveis por uma teoria não se prestam a aferir outras teorias.

Palavras-chave: Princípio da Proliferação. Aferição interdependente. Argumento da eliminação. Méritos relativos.

\begin{abstract}
In order to criticize the defense of the Principle of Proliferation made by Feyerabend we will evaluate to what extent the social sciences benefit from the fact that they shelter a considerable diversity of theories and methodologies. In spite of being a reality in social disciplines, proliferation is never seen as capable of increasing the testing of a theory by contrasting it with alternatives. Social scientists disbelieve that there are potential falsifiers to a theory that only other theories are able to locate. Having to deal with explanatory diversity, the social sciences come into conflict with the thesis that, by virtue of each theory having access only to certain facts, disregarding alternative theories implies let the facts they locate off lightly. The multiplication of theories has been fought by means of the argument by elimination whereby the social theories already formulated are scrutinized with the aim of demonstrating their flaws and pointing out an alternative to them as the only acceptable because it is the only survivor to rigorous empirical evaluation. We will point out the reasons why social scientists make a massive use of the argument by elimination against duplication or multiplication theories. Considering that social theories do not test each other, proliferation is deprived of the epistemic advantages attributed to it by Feyerabend. Even if reciprocal testing is possible it is useless because if there are facts located only by certain theory they do not serve to evaluate other theories.
\end{abstract}

Keywords: Principle of Proliferation .Interdependent evaluation. Argument by elimination. Relative merits.

\title{
Resumen
}

Con el fin de criticar la defensa del principio de proliferación hecha por Feyerabend, evaluaremos hasta qué punto las ciencias sociales se benefician del hecho de que albergan una considerable diversidad de teorías y metodologías. Pesar de ser una realidad en las 
disciplinas sociales, la proliferación nunca se considera capaz de aumentar las pruebas de una teoría contrastándola con alternativas. Los cientistas sociales describen que hay posibles falsificadores de una teoría que sólo diferentes teorías se revelan aptas para localizar. Teniendo que vivir con la diversidad explicativa, las ciencias sociales son contrarias a la tesis de Feyerabendiana de que, en virtud de cada teoría que sólo tiene acceso a determinados hechos, el desprecio de las alteridades deja en la penumbra los hechos localizados por ellas. La multiplicación de las ópticas se ha combatido utilizando el argumento de eliminación mediante el cual las teorías sociales ya formuladas son examinadas con el objetivo de demostrar sus defectos y señalar una alternativa como la única aceptable porque es la sobreviviente de los análisis empíricos. Señalaremos las razones por las que se ha recurrido al argumento de eliminación contra la duplicación y la proliferación de teorías en las disciplinas sociales. La proliferación carece de las ventajas epistémicas atribuidas por Feyerabend teniendo en cuenta que las teorías sociales no se prueban entre sí. Incluso si es posible, las pruebas recíprocas resultan inútiles porque si hay hechos sólo localizables por una teoría no se prestan a medir otras teorías.

Palabras clave: Principio de proliferación. Medición interdependiente. Argumento de eliminación. Méritos relativos.

"A coisa mais importante é compreender que tudo que é fatual já é teoria". (Goethe, 1998, § 575)

"Toda forma de silenciar a discussão é fruto de presunção de infalibilidade". (Mill, 1952, p. 19)

\section{Da proliferação historicamente identificada à metodologicamente idealizada}

Em alguns textos marcantes dos anos 1960 - "How to be a Good Empiricist" (1963), "Realism and Instrumentalism" (1964), "Problems of Empiricism' and 'Reply to Criticism" (1965) - os mais importantes argumentos de Feyerabend a favor do realismo científico são, como ressalta 
Preston (2016), metodológicos: o realismo é desejável porque exige a proliferação de teorias novas e incompatíveis. Encarada como condição de possibilidade para que avanços científicos ocorram, a diversidade explicativa é reputada indispensável para que cada teoria tenha mais conteúdo empírico do que possuiria se isoladamente analisada.

Cantada em prosa e verso por Feyerabend, a proliferação fez parte da história das ciências naturais e se mantém entranhada na paisagem das disciplinas sociais. Pode-se aplicar ao quadro geral ainda encontrável na pesquisa social a tese de Kuhn (1970, p. 77) de que "na ausência de um paradigma, ou de algum candidato a paradigma, todos os fatos que poderiam possivelmente ser pertinentes ao desenvolvimento de determinada ciência têm probabilidade de parecer igualmente relevantes". Seria característica da "pesquisa pré-científica" o estado em que os fatos fomentam, por falta de eficazes dispositivos de seleção da melhor explicação, modalidades variadas e incomensuráveis de teoria, todas em selvagem competição entre si. Mesmo as ciências que passaram a operar sob a égide de um paradigma também podem, caso o paradigma entre em crise, gerar temporariamente - como indica Kuhn (1970, p. 153, grifo nosso) - diversidade explicativa: "a proliferação de articulações competidoras, a propensão a tentar qualquer coisa, a expressão do descontentamento explícito, o recurso à filosofia e aos debates sobre fundamentos, são todos sintomas de uma transição da pesquisa normal para a extraordinária".

O estado em que se encontrava a Óptica antes de Newton é exemplo clássico da desenfreada e improdutiva competição entre teorias. Inúmeras eram as teorias sobre a natureza da luz, sem que alguma tivesse chegado a granjear aceitação geral. Por terem natureza "fundacional", as dissensões repercutiam sobre os modos de identificar os fenômenos observacionais e de hierarquizá-los em termos de sua relevância para a construção e avaliação das teorias. Até Newton, houve quem encarasse a luz como partículas que emanavam dos corpos materiais, como uma interação do meio com uma emanação do olho, como a modificação do meio que intervinha entre o corpo e o olho etc. 
Inexistiu período entre a antiguidade remota e o fim século dezessete que tenha exibido uma única concepção amplamente aceita sobre a natureza da luz. Havia, ao contrário, várias escolas e subescolas em competição [...] cada uma derivava sua força da relação com determinada metafísica e cada uma enfatizava, como observações paradigmáticas, o conjunto particular de fenômenos ópticos que sua teoria poderia melhor explicar. Outras observações eram tratadas por meio de elaborações ad hoc ou permaneciam como problemas pendentes para a pesquisa ulterior. (KUHN, 1970, p. 74-5).

Pode-se também invocar o exemplo da história da pesquisa elétrica na primeira metade do século XVIII, época em que havia tantas concepções sobre a natureza da eletricidade quantos eram os cientistas importantes. Superado o estádio de permanente disputa entre Escolas, tem início a "idade madura", que se caracteriza, entre outras coisas, pela unificação metodológica, linguística e ontológica das práticas de pesquisa executadas sob a batuta de uma teoria consensualmente aceita. Um conjunto de procedimentos, um sistema linguístico e uma moldura ontológica conferem identidade ao paradigma e fazem com que, durante sua vigência, sejam reconhecidos como objetos de estudo apenas certos entia e com que sejam aceitos apenas determinados modos de abordá-los inculcados por meio de uma rígida educação científica. Dado que o paradigma não tem como ser emulado "de fora", nem testado à luz de evidências apreensíveis sem seus filtros, não se formam alteridades durante sua vigência.

O monismo teórico, especialmente o resultante da vigência da ciência normal tal qual historicamente identificada por Kuhn, é encarado por Feyerabend como entrave ao progresso do conhecimento. A veemente defesa do pluralismo leva Feyerabend a revalorizar, quiçá a idealizar, a fase pré-paradigmática da pesquisa e o momento em que o paradigma merguIha em crise. Os cientistas precisam se confrontar com a multiplicação de explicações para que possam promover a forma mais eficaz de aferição 
metodológica: aquela em que as teorias testam umas às outras. À luz dessa visão, a ciência é menos um confronto de uma teoria isolada com fatos e mais uma espécie de "acareação" de uma teoria com suas alteridades.

Partindo da tese de Popper de que a testabilidade de uma teoria é proporcional ao número de falsificadores potenciais que possui, Feyerabend advoga que sem a produção de teorias alternativas não se tem como chegar à identificação de muitos potenciais falsificadores. Reputado indispensável aos avanços científicos, o pluralismo fomenta a formação e a utilização de teorias diferentes, até mesmo incompatíveis, com o objetivo de fazer com que cada uma contribua, por meio de fecunda competição, para aumentar a testabilidade, o conteúdo empírico, das outras.

Pode alegar um kuhniano que se a história comprova que antes de ingressarem na fase em que operam sob a égide de um paradigma as ciências passaram por um período marcado por renitentes e infrutíferas disputas internas, desponta pouco sustentável a proposta, principalmente se feita com impostação normativa, de se dar papel de destaque à proliferação na pesquisa científica. Por entender que proceder de acordo com o Princípio da Proliferação é "um método de precipitar revoluções, um método racional", Feyerabend (1977b, p. 205) acredita legítimo se insurgir contra as práticas estabelecidas da ciência real caso fique demonstrado que desestimulam ou impedem a multiplicação de ópticas sem a qual a testagem das teorias resulta limitada. Contra o monismo metodológico e explicativo, Feyerabend indaga: "é esse o método que a ciência realmente usa ou os cientistas se aferram a seus paradigmas até o fim amargo no qual a repulsa, a frustração e o tédio os impossibilitam de continuar?" De tão incisivas, as críticas ao monopólio explicativo assumem um tom "voluntarista" de concitação à proliferação:

A ideia de que as teorias se mantêm inatacáveis, por decênios e mesmo séculos, até que uma grande refutação surja e as derrube - essa ideia, afirma ele [Kuhn], não passa de um mito. Ora, se isso é verdade, por que não damos imediatamente 
início à proliferação impedindo, em definitivo, a ciência puramente normal de existir? (FEYERABEND, 1977b, p. 207).

Para Kuhn, a formação e a derrocada de um período de ciência normal fazem parte de um processo comunitário que independe de decisões resultantes da deliberação deste ou daquele cientista. A construção do consenso em uma comunidade científica tem aspectos psicossociais em nada afetados pela preferência de cientistas específicos por tal ou qual modelo de pesquisa. Ecoando algumas das duras críticas de Popper (1977, p. 51-58) a Kuhn, Feyerabend propõe que "se dê início imediatamente à proliferação, e que nunca se permita que uma ciência normal venha a existir". Esse posicionamento supõe que a diversidade teórica possa e deva ser deliberadamente estimulada e explorada por ser sua existência indispensável ao progresso da ciência. A educação rígida promotora das rotinas reiterativas da normal science, a insensibilidade a novidades e a ópticas alternativas, levou Feyerabend a acusar Kuhn, como assinala Godfrey-Smith (2003, p. 112), "de encorajar as piores tendências na ciência do século XX: profissionalização, estreiteza mental e exclusão de ideias heterodoxas". Consciente dos exageros críticos, Feyerabend (1995, p. 141) reconhece em sua Autobiografia que seu espírito opositivo chegou a estender-se a ideias semelhantes às suas: "critiquei, por exemplo, o manuscrito de The Structure of Scientific Revolutions lendo-o de maneira antiquada".

Depois de considerar um erro supor necessário conservar um programa de pesquisa até que se tenha esgotado toda a sua força heurística, Lakatos (1977, p. 154-155) reputa igualmente errado deixar de apresentar um programa rival antes de todos terem chegado à conclusão de que foi provavelmente atingido seu ponto de degeneração. Kuhn é atacado por Lakatos como se defendesse normativamente a existência da normal science: "o que ele denomina 'ciência normal' nada mais é que um programa de pesquisa que conquistou monopólio". Afinado com Popper e Feyerabend, Lakatos (1977, p. 155) sustenta que 
a história da ciência tem sido, e deve ser, uma história de programas de pesquisa competitivos (ou "paradigmas"), mas não tem sido, nem deve se tornar, uma sucessão de períodos de ciência normal: quanto antes se iniciar a competição, tanto melhor para o progresso.

Para Feyerabend (1977a, p. 13), a ideia copernicana do movimento da Terra não possuía apoio observacional independente, pelo menos não nos primeiros 150 anos de sua existência, e era "incompatível com fatos e teorias físicas altamente confirmadas; e foi assim que a física moderna começou: não como um empreendimento observacional, mas como uma especulação sem sustentação, incompatível com leis altamente confirmadas". Supondo que as disciplinas sociais tiveram um início parecido com o da fase especulativa da física, com teorias carentes de base empírica, resta saber por que não o superaram. Além de rechaçar a visão de que a crítica onipresente e a proliferação descontrolada caracterizam a fase da pré-ciência, Feyerabend propõe que se impeça a formação de monopólios teóricos dando a impressão de negligenciar o fato de que a competição desenfreada, especialmente nas ciências sociais, não tem se mostrado profícua.

\section{A diversidade explicativa amplia o processo de testagem?}

Braithwaite (1968, p. 368) assim sintetiza a concepção tradicional de método: "o homem propõe um sistema de hipóteses, a natureza define sua verdade ou falsidade; o homem inventa um sistema científico e depois descobre se está ou não de acordo com o fato observado". Feyerabend a rejeita por entender que um sistema explicativo que se submete apenas ao crivo dos fatos localizados por meio de seu próprio spotlight é avaliado de forma limitante. Apresentada, nas palavras de Amsterdamski (1975, p. 20), "como o que nos força a tratar a teoria científica como extraída da experiência", a metodologia tradicional é vista por Feyerabend como geradora de restritivo e infecundo monopólio explicativo: 
Consideremos a regra segundo a qual o sucesso de nossas teorias é medido pela "experiência", pelos "fatos'” ou 'resultados experimentais', de tal modo que a concordância entre uma teoria e os "dados" favorece a teoria (ou deixa a situação inalterada) e a discordância a coloca em risco a ponto de talvez forçar sua eliminação. Parte importante de todas as teorias da confirmação e da corroboração, essa regra é a essência do empirismo. A 'contrarregra' aconselha-nos a introduzir e elaborar hipóteses incompatíveis com teorias bem firmadas ou com fatos bem estabelecidos (FEYERABEND, 1993, p. 20).

Posicionando-se contra as modernas teorias do conhecimento por sua hostilidade à proliferação de ideias, por seu devotamento à eliminação de visões alternativas, Feyerabend (1999a, p. 105) argumenta que no processo de aferição de uma teoria científica é crucial recorrera alteridades, independentemente de terem natureza empírica ou especulativa. $O$ argumento técnico a favor do pluralismo é o de que a testagem só será eficaz se der atenção a teorias alternativas portadoras do poder de propiciarem a identificação de outros fatos, que deixam de ser detectados caso o pesquisador fique adstrito ao domínio empírico delimitado pela teoria preferida. Subsistindo a dependência do que se constata aos óculos teóricos adotados, às alteridades é conferida a capacidade de localizar outros fatos em condições de testar a teoria sub examine:

Além de a descrição de cada fato depender de alguma teoria, que pode ser muito diferente da teoria a ser testada, existem fatos que não podem ser desvelados sem a ajuda de alternativas à teoria a ser testada, que ficam indisponíveis se as alternativas são excluídas. Isso sugere que a unidade metodológica a que devemos nos referir ao discutir questões de teste e conteúdo empírico é constituída por todo um conjunto de teorias parcialmente sobrepostas, factualmente adequadas, mas mutuamente incompatíveis (FEYERABEND, 1977a, p. 27). 
A despeito de ter reconhecido que remonta a Popper a visão de que o pluralismo - concebido como presença simultânea de teorias concorrentes - é precondição para o progresso científico, Feyerabend (1987, p. 289) acusa "os popperianos de pouco conseguirem ir além das formas mais ingênuas de empirismo". Conferindo protagonismo metodológico ao Princípio da Proliferação, Feyerabend acredita poder acalentar a pretensão de originalidade ao conferir à multiplicação de teorias o poder fundamental de propiciar a refutação indireta: "a evidência capaz de refutar uma teoria com frequência só poder ser desvelada com a ajuda de uma alternativa incompatível". Marcantes nas disciplinas sociais, o pluralismo teórico e o metodológico não devem ser confundidos, uma vez que, como assinala Preston (1997, p. 139), "o modelo do teste pluralista almeja ser uma única metodologia para toda a pesquisa científica, serve para fomentar a proliferação de teorias, mas não de métodos para avaliar teorias". O pluralismo teórico e o metodológico passam a andar juntos quando Feyerabend abraça o anarquismo.

Sabidamente, Popper (1996, p. 133-135) assume posição enfática contra o estratagema de introduzir hipóteses ad hoc com a finalidade de salvar artificialmente teorias confrontadas com contraexemplos. Dando enorme destaque à função cumprida pelas teorias alternativas, Feyerabend (1993, p. 14-50) chega a declarar: "há circunstâncias em que é aconselhável introduzir, elaborar e defender hipóteses ad hoc, em contradição com resultados bem estabelecidos e amplamente aceitos, ou hipóteses cujo conteúdo é menor que o da alternativa existente e empiricamente adequada, com hipóteses incompatíveis e assim por diante". O destaque dado às alteridades no processo de avaliação das explicações científicas leva Feyerabend (1981a, p. 107) a recomendar "não só a invenção de novas alternativas como também o posicionamento contra a eliminação de teorias mais antigas já refutadas em virtude de contribuírem para o conteúdo das rivais vitoriosas".

Para Feyerabend, o pluralismo teórico está escorado nas seguintes constatações: 1) fatos não notados anteriormente podem vir a ser identificados atentando-se para alteridades; 2) fatos antes reputados triviais ou desimportantes podem subitamente adquirir relevância. Por melhor que seja 
a teoria favorita, seu valor não tem como ser atestado isoladamente, sem passar por crivos providos por alternativas. Dada uma teoria $T$, especificadora de um domínio factual $F$, a geração de alteridades a $T$ aprofunda o processo de testagem de $T$ à medida que enseja a identificação de outros fatos, não detectáveis por $T$, mas capazes de avaliar T. A suposta dependência da constatação de fatos à variedade de ópticas teóricas é o pilar central da defesa do Princípio da Proliferação. Em razão de fatos iluminados por determinado holofote teórico não o serem por outros, a metodologia apropriada precisa se assentar no pluralismo ativo. Antes de Feyerabend, Whitehead (1961, p. 221) já sublinhara que "uma grande parte do pensamento filosófico confuso tem origem no esquecimento do fato de que a relevância da evidência é ditada pela teoria". Visto que fatos não são sic et simpliciter constatados, mas selecionados, Whitehead conclui "que não se tem como provar uma teoria pela evidência que ela descarta como irrelevante [...] É impossível saber o que procurar e como conectar observações esporádicas”.

Em alguns textos, Feyerabend (1981a, p. 104-131, 1993, p. 46) apresenta o Princípio da Proliferação como indispensável ao crescimento do conhecimento e à obtenção do conhecimento objetivo. Em outros, Feyerabend (1993, p. 29 e 41) o considera imprescindível por sua capacidade de fomentar uma forma mais ampla e aprofundada de "testagem de teorias" baseada no reconhecimento de que a identificação de evidência capaz de detectar erro, até de refutar uma teoria, costuma ser feita por outra teoria. O Princípio da Proliferação é enaltecido metodologicamente pelo poder de ampliar o processo de avaliação das teorias, culturalmente por ser a expressão do respeito a diferentes estilos de vida e filosoficamente por representar a receptividade a divergentes modos de pensar.

Em termos metodológicos, Feyerabend alicerça a proliferação nas seguintes teses: (1) se uma visão pode ser verdadeira ainda que se tenha razão para rejeitá-la, negar isso equivale a se considerar infalível; (2) como sói ocorrer, uma visão problemática pode conter uma parcela de verdade; uma vez que a opinião predominante sobre qualquer assunto raramente ou nunca representa toda a verdade, o restante da verdade só tem alguma chance de ser provido 
pela colisão de opiniões adversas; e (3) mesmo um ponto de vista verdadeiro, mas não contestado, vai ser sustentado à maneira de um preconceito, com pouca compreensão ou apreensão de seus fundamentos racionais. As duas primeiras são consideradas respaldadas pela história da ciência.

Feyerabend (1993, p. 20-21) é de opinião que "o conselho que remonta a Newton, ainda muito popular, de usar alternativas somente depois de as refutações terem desacreditado a teoria ortodoxa equivale a colocar o carro na frente dos bois". Os melhores ditames empiristas se distinguem, segundo Feyerabend, pela preocupação em ampliar o campo de testagem da teoria favorita fazendo-a interagir com alteridades. Sem diversidade explicativa se é incapaz de evitar a "cumplicidade" entre uma teoria e seus fatos - os que ela logra identificar. As diretrizes metodológicas afinadas com a defesa da proliferação não têm como ser seguidas pelas ciências maduras nas quais o monismo teórico tem-se revelado bem-sucedido; e não têm como ser consideradas profícuas nas disciplinas sociais com uma história marcada pela variedade teórica combatida sem sucesso. Supondo que o Princípio da Proliferação está respaldado por uma constatação - a de que a teoria avaliada no domínio empírico por ela mesma localizado e demarcado enseja apenas a realização de testes parciais - Feyerabend o formula com teor prescritivista operando a problemática transição do é para o deve:

O cientista que deseja ampliar ao máximo o conteúdo empírico das concepções por ele sustentadas, que almeja entender essas concepções tão claramente quanto possível, deve, portanto, introduzir concepções novas. Por mais que uma teoria pareça refletir fidedignamente os fatos, por mais universal que seja seu uso, sua adequação fatual só pode ser afirmada depois de confrontada com alternativas cuja invenção e desenvolvimento detalhado devem preceder qualquer afirmação final sobre o sucesso prático e a adequação fatual. Esta é a justificação metodológica de uma pluralidade de teorias (FEYERABEND, 1977a, p. 40, grifo nosso). 
É preciso adotar a pressuposição de que inexiste acesso universal aos fatos, e a suas relações, para se advogar que só recorrendo a variados óculos teóricos se evita que a aferição metodológica de uma teoria seja limitada e parcial. Se contrastar teorias fosse o meio mais eficaz de avaliá-las, inexistiriam práticas consagradas de pesquisa capazes de estipular padrões de solução para conjuntos específicos de problemas. Visto que os cientistas descreem que uma teoria possa identificar o que passa despercebido por outra, Feyerabend confere tom normativo à sua pregação:

O cientista que deseja ampliar ao máximo o conteúdo empírico das visões que sustenta [...] deve introduzir outras visões, ou seja, deve adotar uma metodologia pluralista. Cabe-Ihe comparar ideias com outras ideias mais do que com a 'experiência', tentar antes aperfeiçoar que descartar as visões que fracassarem na competição. Procedendo dessa maneira, reterá as teorias acerca do homem e do cosmos que se encontram no Gênese ou no Pimandro e as elaborará e utilizará a fim de avaliar o êxito da evolução e de outras visões 'modernas' (FEYERABEND, 1993, p. 21, grifo nosso).

Para se entender o alcance do Princípio da Proliferação, é fundamental ter presente que Feyerabend vai além do reconhecimento - como aponta Laudan (1996, p. 107) - de que "uma teoria costuma ser demasiado incompleta para nos levar à descoberta de todos os 'fatos' sobre o mundo. Feyerabend tampouco se limita a retomar a conhecida tese de Duhem de que para se testar uma teoria normalmente são exigidas várias teorias colaterais". Mais que proclamar que uma teoria rival, $T c$, à teoria em teste, $T b$, ensejará encontrar casos que refutem $T b$, o que Feyerabend defende - como mostra Laudan - é que certos casos refutadores de Tb só podem ser 'identificados' caso sejam exploradas as contrárias de Tb. Contra o arrazoado feyerabendiano, há o fato de que as tantas teorias produzidas 
pelas Escolas aninhadas nas ciências sociais em nada têm contribuído para promover, e muito menos para trivializar, as refutações indiretas.

Sem indicar precisamente de que modos diferentes teorias podem interagir - com suas especificidades sintáticas e semânticas - em prol de uma avaliação mais profunda e abrangente de cada uma, Feyerabend atrela o objetivo de viabilizar a maior testabilidade possível à suposição de que as debilidades da teoria preferida só são em geral detectadas recorrendo-se ao maior número alcançável de teorias rivais. A despeito de marcadas por um histórico de contraposições teóricas, as ciências sociais não comprovam as vantagens da proliferação assim elencadas por Feyerabend: 1) a relevância epistêmica de certos fatos para a aferição de certas teorias só pode ser reconhecida ou estabelecida por meio do desenvolvimento de alternativas à teoria a ser avaliada; 2) o caráter refutador de certos fatos em condições de falsificar uma teoria só pode ser mostrado recorrendo-se à exploração de teorias rivais. Na avaliação de Laudan (1996, p. 105-110), Feyerabend nunca oferece um argumento independente para (1) em virtude de sua dependência a (2). A tese (2) é exposta detalhadamente porque se a proliferação enseja a refutação não se pode negar sua relevância. Laudan acredita que "essa tática ricocheteia porque os argumentos de Feyerabend em prol da proliferação propiciadora de refutação não são suficientemente fortes". A crítica de Laudan encontra respaldo nas disciplinas sociais, que enfrentam dificuldades para levar a cabo tanto a testagem direta quanto a que afere teorias à luz de fatos identificáveis por alteridades.

Os fatores semânticos e pragmáticos que dificultam o intercâmbio crítico entre mesmo e outro são negligenciados por Feyerabend (1977a, pp. 14-5) quando recorre à pregação genérica de que "a função das alternativas concretas é a de fornecer meios de criticar a teoria aceita de uma maneira que vai além da crítica suprida por uma comparação dessa teoria 'com os fatos'”. Se a desconsideração de alteridades conduzisse à adoção de procedimentos de aferição incompletos em razão de as teorias precisarem ser avaliadas por cotejo com fatos apreensíveis pelas rivais, então parte significativa das teorias até hoje aceitas nas ciências maduras 
teria sido insuficientemente testada. Se o conteúdo empírico da teoria $T$ se condenasse a ser o que a tessitura de sua óptica explicativa lhe permite apreender, de tal modo que ficar adstrito a $T$ é ver somente determinadas coisas, então as teorias sociais passariam por crivos mais amplos e teriam, em conjunto, uma abrangência ontológica maior. A argumentação em prol do pluralismo relativiza o apoio que uma teoria recebe diretamente dos fatos tornando sua avaliação dependente dos fatos apreensíveis por alteridades.

A "interdependência teórica" é assim formulada por Feyerabend (1977a, p. 15):

Por mais que uma teoria pareça refletir fidedignamente os fatos, por mais universal que seja seu uso [...] sua adequação factual só pode ser afirmada depois de ter sido confrontada com alternativas cuja invenção e desenvolvimento detalhado devem preceder qualquer afirmação final de sucesso prático e adequação factual.

Tal visão culmina na tese de Feyerabend (1999a, p. 107-8) de que "uma teoria $T$ não pode ser removida por experimentos discordantes", uma vez que "podendo as teorias ser desenvolvidas e aprimoradas, sua relação com a observação é também passível de modificação". Com o intuito de tentar evitar que a preservação de teorias gere o tipo de diaphonia presente nas ciências sociais, Feyerabend ressalva ser "racional afastar $T$ se existir outra teoria $T$ ' que acentua as dificuldades de $T$ (e, portanto, é incompatível com $T$ ) e que, ao mesmo tempo, promete meios para sua remoção abrindo novos caminhos de pesquisa".

Ao defender que "uma ciência livre de metafísica está no melhor caminho para se tornar um sistema metafísico dogmático", Feyerabend (1977a, p. 15) indica acreditar que a busca de conhecimento científico envolve sempre escolher um conjunto específico de pressuposições absolutas que, como as caracteriza Collingwood (1948, p. 32), definem modos de selecionar e olhar os fatos a despeito de se mostrarem insuscetíveis de avaliação empírica. 
As pressuposições absolutas levam à elaboração de diferentes espécies de teoria, cada uma apta a acessar uma modalidade específica de enredo fatual em detrimento da identificação de outros tipos de evidência empírica. Visto que a alteridade a uma teoria científica pode ser, para Feyerabend, não só outra teoria científica, mas também uma metafísica, um sistema especulativo ou mesmo uma doutrina religiosa, o processo de avaliação do que se alega ser conhecimento científico deixa de ficar circunscrito aos limites da pesquisa empírica, de tal modo que são eliminadas as fronteiras traçadas pelos critérios de cientificidade/demarcação:

Sistemas metafísicos são teorias científicas em seu mais primitivo estágio. Caso contradigam um ponto de vista bem confirmado, isso indica sua proficuidade como alternativa a esse ponto de vista. Alternativas revelam-se indispensáveis se acalentamos propósitos críticos. Destarte, sistemas metafísicos que contradizem resultados observacionais ou teorias bem confirmadas são pontos de partida que devem ser bem-vindos quando se tem em mira propósito crítico. (FEYERABEND, 1977a, p. 37).

Suprimidas as fronteiras entre o empírico e o especulativo, Feyerabend (1977a, p. 15) sustenta que "ideias metafísicas incomuns, construídas de forma não dogmática e desenvolvidas com detalhamento suficiente para dar uma explicação (alternativa) até mesmo das situações experimentais e observacionais mais comuns, desempenham papel decisivo na crítica e no desenvolvimento daquilo em que geralmente se acredita e que se mostra 'altamente confirmado'". Chegando a advogar que um bom empirista deve ser um metafísico crítico, Feyerabend (1977a, p. 39) apresenta a proliferação como o único meio de se evitar a entronização artificial e injusta de um ponto de vista: "longe de aumentar o conteúdo empírico das teorias remanescentes, a eliminação de toda metafísica, pode acabar por transformar essas teorias em dogmas". Nunca fica demonstrado que sistemas 
explicativos fundados em diferentes pressuposições absolutas se mostram empiricamente complementares e relevantes uns para os outros a ponto de propiciarem um mais amplo e minucioso processo de testagem de cada um.

Contra a tendência dos cientistas naturais a atribuir graus de confirmação às teorias à luz do conjunto de evidências disponíveis, Feyerabend (1986, p. 71-72) privilegia o pluralismo de um modo que faz com que "a estabilidade do conhecimento não tenha mais como ser garantida" por mais que o suporte dado pela observação a uma teoria seja convincente, por mais que seus fundamentos despontem sólidos. No entanto, Feyerabend (1977a, p. 15) se diz preocupado em aprimorar as formas e meios de controle empírico a ponto de sublinhar que seu "método ainda retém um elemento essencial do empirismo: a decisão entre teorias alternativas baseia-se em experimentos cruciais" por mais que ressalve que cabe "restringir o alcance desses experimentos em virtude de funcionarem bem com as teorias de um grau de generalidade baixo".

Difícil especificar que condições podem viabilizar um profícuo intercâmbio crítico entre mesmo e outro quando se pensa, como Feyerabend (1993, p. 21), que a pesquisa navega em "um oceano em expansão de alternativas mutuamente incompatíveis, talvez até mesmo incomensuráveis, no qual cada teoria singular, conto de fadas ou mito, é parte do conjunto que força as demais a manterem uma articulação maior, e todas contribuindo, via esse processo de competição, para o desenvolvimento de nossa consciência". A crença de que a aferição extensiva de uma teoria não tem como ser feita isoladamente, mas também que todo conteúdo ideacional - seja religioso, metafísico ou ficcional - é relevante para a aferição de uma explicação científica, conduz Feyerabend (1981a, p. 105) a propor a inclusão de "mitos, ideias políticas, sistemas religiosos" no conjunto das alteridades possíveis. A defesa da proliferação chega ao ápice quando Feyerabend (1977b, p. 210) prega ser "desnecessário suprimir até mesmo o mais bizarro produto do cérebro humano".

Feyerabend (1981b, p. 139) se diz seguidor das recomendações de J. S. Mill em prol da busca da proliferação não só de pontos de vista como de 
formas de vida. Entretanto, Feyerabend (1993, p. 37) contraria a pregação libertária de Mill quando defende que a proliferação "seja imposta de fora e por meios políticos em virtude de, com frequência, ocorrer de partes da ciência se tornarem endurecidas e intolerantes". Mesmo reconhecendo que o sucesso da intervenção não tem como ser garantido, como bem evidencia o caso Lysenko, Feyerabend acredita ser imprescindível "a necessidade de controles não científicos sobre a ciência". Em desarmonia com seu tão alardeado posicionamento "libertário", Feyerabend concede que "a proliferação pode ter de ser imposta por agências não científicas cujo poder se mostre suficiente para superar as instituições científicas mais poderosas". Tal tipo de argumentação conflita com a recorrente pregação "libertária" de Feyerabend (1978, p.117): "uma pessoa que tenta resolver um problema, na ciência ou alhures, deve desfrutar de completa liberdade, não podendo ser restringida por exigências ou normas por mais que pareçam plausíveis ao lógico ou ao filósofo". O fato de pensar que "normas e exigências devem ser controladas pela pesquisa e não se recorrendo a teorias da racionalidade" não impediu Feyerabend (1995, p. 146) de reiterar na Autobiografia um viés "intervencionista": "a sugestão de que a ciência deveria ser submetida ao controle público não é tão radical quanto soa; a ciência não é o empreendimento "livre" e "aberto" com que sonham os filósofos".

\section{A improficuidade da proliferação nas ciências sociais}

O entendimento de Feyerabend (1999a, p. 110) de que "a proliferação é necessária ao fortalecimento dos testes e ao desvelamento de fatos refutadores que, de outro modo, se mantêm inacessíveis" não tem sido compartilhado pelos cientistas sociais que, confrontados com a diversidade explicativa, se empenham em superá-la. Diferentemente da economia, na qual se reconhece a existência de um mainstream, nas ciências sociais em geral têm se desenvolvido diferentes linhas de pesquisa sem que nenhuma desfrute de hegemonia explicativa. A atenção à história das disciplinas 
sociais permite constatar que falta respaldo à tese de Feyerabend de que a proliferação é metodologicamente indispensável porque enseja, entre outras coisas, que cada teoria contribua para uma mais aprofundada testagem de outra(s). Com todas as suas Escolas e subescolas, as disciplinas sociais produzem uma diversidade explicativa que, a despeito de sua riqueza, fica longe de gerar as vantagens epistêmicas que Feyerabend Ihe atribui. Por essa razão, os pesquisadores sociais têm combatido a proliferação por meio de procedimentos metodológicos seletivos devotados a afastar as teorias já propostas com o fito de conceder autoridade explicativa à nova, apresentada como a única sustentada pelos fatos.

Defendemos a tese de que as disciplinas sociais, com sua endêmica proliferação, fornecem evidências que contrariam a visão de que sem a multiplicação de ópticas o "progresso na ciência é impensável". É discutível a alegação de que a refutação se torna esporádica, senão impossível, caso se deixe de levar em consideração fatos supostamente localizáveis por outros pontos de vista. Nos domínios do saber em que a multiplicação de visões é uma realidade, inexiste a comprovação deque a testagem de uma teoria é ampliada e aprofundada atentando-se para fatos apreensíveis por alteridades. Por essa razão, mantém-se atual a comprovação de Bottomore (1972, p. 29) de que "inexiste no momento um corpo geral de teoria sociológica que tenha sido comprovado ou tenha-se tornado amplamente aceito". O pluralismo teórico é filho da multiplicação de métodos, e vice-versa, a ponto de permanecer válido o veredicto de Poincaré (1912, p. 12-13): "cada tese sociológica propõe um método novo [...] o que faz com que a sociologia seja a ciência com o maior número de métodos e o menor número de resultados". Por falta de crivos metodológicos consensualmente acatados e comprovadamente eficazes, as ciências sociais abrigam uma crescente proliferação de teorias.

A despeito de tratar reiteradamente de temas sociais e políticos associáveis à ciência, Feyerabend pouco se debruça sobre a problemática da metodologia adequada ao estudo dos fatos sociais. Apresentando-se como seguidor de J. S. Mill, Feyerabend (1986, p. 70-71) sustenta de forma 
genérica que "uma epistemologia pluralista deve ser defendida tanto para as ciências naturais quanto para as sociais". O problema é que nas disciplinas sociais o pluralismo é historicamente uma realidade e se manifesta por meio de controvérsias endêmicas que começam na metodologia, passam pela ontologia e podem chegar à axiologia. $\mathrm{O}$ evolver das ciências sociais é pouco harmonizável com a tese feyerabendiana de que fatos (pretensamente) só localizáveis por uma teoria sejam relevantes - e sejam assim reconhecidos - para o processo de avaliação crítica de outra(s). A propensão a depreciar a proliferação como característica da pré-ciência tem favorecido o diagnóstico questionável de que o "subdesenvolvimento" das disciplinas sociais, a falta de concessão consensual de monopólio explicativo a uma teoria, resulta principalmente do descaso pelo emprego do genuíno método empírico. Independentemente de se é causa ou efeito das guerras intestinas na psicologia, sociologia, economia, politologia etc., o Methodenstreit desponta atrelado à fragmentação explicativa.

Nutrindo grande admiração filosófica pelo Mill (2001, p.19) de On Liberty, entusiasta defensor da proliferação considerada antídoto à falibilidade humana, Feyerabend pouca afinidade possui com o Mill (1949, Livro III, p. 253) de A System of Logic que propõe, de forma rígida, "quatro métodos de investigação experimental". Decerto Feyerabend discorda de Mill (1949, Livro VI, p. 545) quando sustenta que "o estado de atraso no qual se encontram as Moral Sciences só pode ser remediado por meio da aplicação dos métodos da Ciência Física, devidamente estendidos e generalizados". Contra a prescrição de as disciplinas sociais imitarem as naturais para se tornarem genuínas ciências, Feyerabend está mais próximo do diagnóstico de Kuhn (1970, p. 58):

[...] tanto a História quanto meus conhecimentos me fizeram duvidar de que os praticantes das ciências naturais possuam respostas mais firmes ou mais permanentes para tais questões [natureza do método e problemas científicos legítimos] do que seus colegas das ciências sociais. 
Tendo sua história marcada por obras que se veem obrigadas a dedicar espaços generosos à defesa de determinada concepção de método, as disciplinas sociais colocam em xeque a proficuidade da proliferação de procedimentos de pesquisa e dos diferentes resultados que permitem alcançar. A proposição de distintas metodologias gera explicações - como, por exemplo, a do materialismo histórico e a da sociologia compreensiva - que pouco ou nada se beneficiam de suas profundas divergências. Isso pode ser ilustrado pelos modos com que Marx e Weber encaram as relações entre, por exemplo, economia, religião e ética. A inexistência de critérios compartilhados capazes de estabelecer méritos relativos entre as teorias sociais torna a proliferação geradora de entrincheiramento explicativo e não de testagem mais ampla e acurada. A ausência de um método com unwritten rules, consensualmente aplicadas, se deve ao fato de os tipos de explicação buscados e as técnicas de pesquisa adotadas se revelarem fundamentais para definir a identidade de cada Escola.

Feyerabend acredita que ampla aceitação não significa sucesso explicativo, mas incapacidade da razão de elaborar alternativas que se prestem a testar a teoria preferida. Visto que nas disciplinas sociais falta endosso maciço a uma teoria, não há como confundi-lo com sucesso explicativo; a mais aceita, fruto ou não de modismo, fracassa em comprovar que possui maior capacidade explicativa que as alteridades. Cercadas de rivais, as teorias sociais suscitam dificuldades especiais para ser avaliadas isoladamente e mais ainda para ser testadas à luz de fatos que só alternativas se mostram (supostamente) aptas a identificar. À semelhança da filosofia, as disciplinas sociais se destacam pela ausência do que Schumpeter (1950, p. 82-83) chama de destruição criadora e que pode ser ilustrada na economia pela substituição da carroça pelo automóvel. Inexistindo no universo da pesquisa a substituição da teoria inferior pela acolhida consensualmente como superior, a eficiência explicativa deixa de poder ser objetivamente estabelecida. Por certo a proliferação presente nas ciências sociais não tem contribuído para o progresso cumulativo, pois, como observa Jarvie (1986, p. 4-5), "se hoje mais fenômenos naturais são 
explicáveis do que em 1578, é no mínimo discutível que atualmente mais fenômenos sociais sejam explicáveis do que em 1578".

Feyerabend (1999a, p. 110) sustenta que "a crítica é facilitada pela proliferação, que evita que trabalhemos com uma única teoria, um sistema de pensamento, um quadro institucional, até que as circunstâncias nos forcem a modificá-lo ou a abandoná-lo". Ainda que a contraposição se preste a evitar o tipo infecundo de monopólio teórico, é discutível que enseje a testagem recíproca das teorias. Feyerabend pode estar certo em advogar que "usamos uma pluralidade de teorias (sistemas de pensamento, quadros institucionais) desde o início" sem que isso implique que é sempre necessário conservar a diversidade explicativa. As disciplinas sociais vêm desde sua inauguração discutindo que concepção de cientificidade pode ser compartilhada por suas diferentes Escolas também com o objetivo de eliminar a proliferação.

Por mais que os procedimentos de avaliação metodológica não devam se limitar ao cotejo de uma teoria com um conjunto fixo de enunciados observacionais, não se justifica conferir protagonismo à proliferação caso se fique longe de constatar que teorias alternativas cumprem papel decisivo na testagem, entendida como tentativa de refutação, da teoria-protagonista. O Princípio da Autonomia - para o qual os fatos indispensáveis para aferir uma teoria são localizáveis sem que haja necessidade de se dispensar atenção às teorias alternativas - tem sido perfilhado pelos cientistas sociais apesar de sempre terem diante de si a realidade da proliferação e a possibilidade de tirar proveito dela.

Em debate ocorrido em Tübingen em torno da cientificidade das disciplinas sociais, Habermas (1977, p. 203) critica Popper por defender "a independência epistemológica dos fatos frente às teorias incumbidas de apreender descritivamente esses fatos e as relações entre eles". Para Habermas, a tese de que "testes examinam as teorias contrapondo-as a fatos 'independentes' é o pivô da problemática positivista residual em Popper". Em texto praticamente da mesma época, Feyerabend (1977a, p. 15) elabora argumentação parecida contra a existência de fatos independentes: "a pluralidade enseja uma crítica mais acurada das ideias aceitas que a comparação com um domínio 
de 'fatos', que se acredita estar ali independentemente de considerações teóricas". Inexistindo fatos independentes, resta saber por que cientistas sociais nunca atribuem à proliferação a vantagem de propiciar a identificação de contraexemplos a uma teoria por meio das lentes de outras teorias. Se a avaliação metodológica confinada à relação entre a teoria preferida e os fatos por ela capturados estivesse condenada a desconsiderar os muitos outros fatos que se pode apreender com teorias rivais, as disciplinas sociais abrigariam - com sua diversidade explicativa - teorias com maior potencial de testagem, de refutação indireta, que as naturais.

Convencido de que os períodos de monismo teórico são sempre prejudiciais ao avanço do conhecimento, Feyerabend (1981b, p. 140) vincula ao Princípio da Proliferação um tipo sui generis de competição no qual vencedores nunca devem ser proclamados: "o surgimento, sucesso e triunfo de uma nova teoria, ponto de vista ou filosofia, quase sempre leva a uma considerável diminuição da racionalidade e da compreensão". Curiosamente, o panorama considerado ideal por Feyerabend é próximo do encontrável na história das disciplinas sociais: ausência de vencedores (consensualmente) proclamados. O problema é que não sendo universalmente reconhecida, a superioridade explicativa é sempre atribuída por uma teoria a si mesma. A pesquisa social parece respaldar a alegação de Feyerabend de que enunciados observacionais podem ser corrigidos e reinterpretados à luz de novas teorias, de que não se pode contar com uma linguagem observacional neutra capaz de realizar avaliações independentes das teorias. No entanto, a falta de uma linguagem observacional compartilhada dificulta o intercâmbio crítico entre as teorias sociais.

As diversas teorias encontráveis em psicologia e sociologia podem representar modos diferentes de olhar os fatos sem que disso resulte que cada uma detenha uma chave própria de acesso a determinados fatos. Recusando "a distinção entre fatos empíricos e teóricos", Feyerabend (1987, p. 289, grifo do autor) poderia encontrar nos estudos sociais respaldo para a tese de que "todos os fatos são teóricos e não apenas carregados de teoria". Isto porque modalidades importantes de fatos sociais são portadoras de 
significatividade intrínseca no sentido de que se oferecem pré-interpretados à observação, ou seja, acompanhados da compreensão que os socii dão a eles.

A tese de que antolhos teóricos conduzem cada construção explicativa a apreender certos fatos deixando outros na penumbra, a delimitar um território em detrimento do descortino de outros solos localizados por teorias alternativas, a diminuir a capacidade de uma teoria de se submeter a testes fazendo-a ignorar fatos apontáveis por rivais, negligencia que os fatos indigitados, por exemplo, pelo materialismo histórico de Marx não são vistos por Weber como capazes de testar sua teoria fundada em outras pressuposições absolutas. É questionável a presunção de que fatos que permanecem inapreensíveis pelo radar de uma teoria social são capturáveis por rivais. Se há fatos localizáveis por alteridades não têm sua serventia reconhecida para a aquilatação da teoria predileta.

As disciplinas sociais parecem respaldara avaliação de Worral (1978, p. 75-200) de que é, no mínimo, controversa a tese de que o conteúdo empírico de uma teoria é dependente do de suas rivais. Falta a comprovação de que o acesso às variadas topografias do mundo social é facilitado pela possibilidade de se trafegar por estradas construídas por diferentes teorias. Caso inexistisse acesso universal aos fatos a ponto de se tornar imperioso contrastar uma teoria com o maior número possível de alternativas a fim de se alcançar um mais amplo mapeamento das variadas "paisagens" do mundo social, bem como uma testagem mais aprofundada, as Escolas presentes nas ciências sociais reuniriam, mais que as naturais, condições propícias à avaliação recíproca de suas teorias.

Se cada teoria das ciências naturais estivesse condenada a apreender apenas alguns fatos, lançando sombra sobre outros, adstringir-se ao crivo das evidências por ela identificadas equivaleria a submetê-la a crivos que propiciam apenas formas "redundantes" de confirmação. O Princípio da Proliferação torna a ontologia ancila da teoria na medida em que o rastreamento e o mapeamento do que existe passam a depender das ópticas criadas e por criar. Nega-se qualquer grau de autonomia à observação quando se advoga que os fatos - com destaque para os capazes de refutar - apreensíveis por 
certas teorias não o são por outras. Se a variedade do que há só é localizável por meio do manejo de diferentes holofotes cria-se uma interdependência ontológica entre as teorias existentes e as que virão a ser elaboradas.

Se na identificação do que é o caso, a teoria que encara a si mesma como uma mônada fica sem ter acesso aos fatos localizados pelas janelas das rivais, as disciplinas sociais fracassam em tirar proveito da diversidade explicativa que abrigam. Por mais que fomentem uma variedade de ópticas, os objetos sociais têm sido considerados mapeáveis sem a necessidade de tornar a aferição de uma teoria dependente dos óculos de alternativas. Navegando em um oceano de muitas ilhas, o barco da pesquisa social sempre buscou chegar ao porto do conhecimento levado pelo leme da teoria sobrevivente. O problema é que inexiste consenso em torno de qual teoria social, dentre as concorrentes, logrou superar as ondas encapeladas dos controles empíricos para chegar ao território no qual comprovou ser uma maior aproximação à verdade. A tentativa de absorver contribuições de diferentes matrizes explicativas sempre foi encarada pelos cientistas sociais como expressão de infecundo ecletismo.

Empregados nas ciências sociais, os procedimentos verificacionistas/ confirmacionistas e os refutacionistas/eliminacionistas têm-se mostrado ineficazes sem que isso seja consequência de existirem fatos que só se tornam localizáveis recorrendo-se a alteridades. É artificial destacar a refutação indireta, a que depende de se dar atenção às alteridades, se nas disciplinas sociais não se consegue sequer alcançar a confirmação gradual e crescente de teorias isoladas. Apesar de conviverem com a proliferação, os pesquisadores sociais se mostram alinhados coma regra da tenacidade assim enunciada por Putnam (1963, p. 772): “uma vez aceita, uma hipótese só será subsequentemente abandonada caso se torne incompatível com os dados". Sublinhando serem as ideias frequentemente rejeitadas antes de poderem mostrar sua força, Feyerabend (1977b, p. 203) propõe uma versão da tenacidade que "exige que a hipótese seja mantida mesmo que haja dados com ela incompatíveis". A prevalecer a concepção feyerabendiana de tenacidade, deixam de ocorrer mudanças. A conservação de teorias nas disciplinas sociais não 
ocorre pela necessidade, apontada por Feyerabend, de se estar "preparado para usar uma multiplicidade de teorias mutuamente incompatíveis em qualquer etapa do desenvolvimento de nosso conhecimento", mas sim por falta de crivos aptos a estabelecer, de modo consensual, méritos relativos.

Como o exemplifica o longevo debate entre os defensores do holismo/ coletivismo e os do individualismo metodológico, as teorias sociais não são empiricamente complementares a ponto de identificarem fatos diferentes capazes de propiciarem a testagem recíproca. O individualismo tem-se revelado incapaz de apreender com exclusividade fatos que reconhecidamente se habilitem a testar o coletivismo metodológico, e vice-versa. Condenando o monismo teórico com base na alegação de que "conduz à eliminação de evidências, que poderiam se prestar a criticar a teoria defendida, de que diminui o conteúdo empírico dessa teoria a ponto de poder torná-la um sistema metafísico dogmático", Feyerabend (1965, p. 149-150) negligencia que o monopólio explicativo tem "espontaneamente" predominado nas ciências naturais e que nas sociais tem sido buscado sem sucesso.

Livres do monopólio explicativo, os cientistas sociais enfrentam cotidianamente o desafio de justificar a opção por um caminho teórico para o qual existem bifurcações derivadas do acolhimento de outras constelações de pressuposições absolutas. Os founding fathers das ciências sociais, e muitos de seus continuadores, podem ser classificados de metafísicos críticos na medida em que assentam suas teorias sobre pilares filosóficos impermeáveis a crivos empíricos. A dialética de Marx sem a filosofia de Hegel, a concepção de ciência de Durkheim sem o empirismo de Bacon e Mill e Weber sem o neokantismo, não teriam como formular e fundamentar suas teorias do jeito que o fizeram. As dificuldades para promover a avaliação objetiva das subjacentes matrizes filosóficas ajudam a entender por que não encontra confirmação nas disciplinas sociais a tese feyerabendiana de que a proliferação cumpre a missão de tornar possível uma modalidade essencial de aferição- aquela em que as divergências entre as teorias ensejem que cada uma teste a outra. 
A diversidade explicativa desponta disfuncional na medida em que provoca a defesa entrincheirada de posições epistemológicas, ontológicas e axiológicas, como fica claro nos casos em que as teorias sociais atacam os fundamentos umas das outras impedindo um efetivo intercâmbio crítico até mesmo no interior de uma mesma Escola de pensamento, como bem o ilustram, por exemplo, o "marxismo de matriz hegeliana" da Escola de Frankfurt e o "marxismo científico", que Althusser desvincula de Hegel. É importante notar que se por um lado Feyerabend (1999b, p. 50) julga "as disputas entre as Escolas como a pior coisa, o perene escândalo da filosofia, em virtude de inexistir problema amplamente aceito, ponto de vista considerado obrigatório para todos, de tal modo que parece possível propagar os maiores absurdos apresentando-os como princípios de uma nova Escola", por outro, deixa de reconhecer que nas disciplinas sociais a proliferação gera um quadro bem parecido. Além de carecer do poder de fomentar o contraste entre teorias de um modo que as torne mais bem testáveis, a proliferação tem gerado nas disciplinas sociais, à semelhança do ocorre na filosofia, a formação de ismos autossubsistentes.

Havendo a necessidade, como advoga Feyerabend (1993, p. 22-23), de "um padrão externo de crítica, de um conjunto de suposições alternativas, de um mundo de fantasia para descobrir os traços do mundo real, da invenção de um sistema conceitual novo capaz de suspender ou antagonizar os resultados observacionais mais cuidadosamente estabelecidos", abre-se também caminho para devotar desnecessariamente atenção a conteúdos em si mesmos inúteis ou irrelevantes para o tipo de estudo desenvolvido. A recomendação de Feyerabend de que é imperioso "entrar em conflito com os mais plausíveis princípios teóricos introduzindo percepções que não façam parte do mundo perceptual existente" é amplamente seguida na história da filosofia e está na origem da desenfreada formação de ismos.

O arrazoado de Feyerabend (1977a, p. 15) de que "a crítica deve usar alternativas, que serão tanto mais eficientes quanto mais radicalmente diferirem do ponto de vista a ser investigado, a ponto de poder acontecer de as alternativas não compartilharem um único enunciado com as teorias 
que criticam", suscita a questão de se "completos estranhos" conseguem de facto entabular um tipo de diálogo que transforme cada um em alteridade (crítica) do outro. A falta de referentes compartilhados gera "abismos ontológicos" que impedem que diferentes teorias - como o ilustra o debate entre individualismo e coletivismo - construam "pontes" semânticas indispensáveis para que se tornem alteridades umas para as outras.

\section{O combate à proliferação de teorias sociais}

A história das disciplinas sociais desmente que a diversidade explicativa proporcione a realização detestes mais abrangentes das teorias. Por mais que cada Escola das ciências sociais questione o núcleo duro da outra, suas conflitantes teorias se agarram a enredos explicativos nada receptivos a eventuais fatos que uma possa apontar para a outra. Visto que as teorias se mostram incapazes de testar umas às outras, os pesquisadores sociais têm tratado a proliferação como uma espécie de "barba de Platão" a ser escanhoada pela navalha de Occam do argumento da eliminação. Diante da multiplicação de explicações prevalecem as tentativas de afastar as reputadas inconsistentes ou falsas para que a remanescente seja acolhida como verdadeira. O propósito do emprego do argument by elimination tem sido, como destaca Lukes (1977, p. 31-33), o de descartar as explicações já formuladas - julgadas erradas ou defeituosas - em prol do endosso da única (supostamente) respaldada nos fatos. As teorias sociais formuladas são escrutinadas com o objetivo de refutá-las e de conferir de modo indireto autoridade explicativa à teoria preferida. O pressuposto, nesse caso, é o de que a cientificidade só é alcançável quando se chega ao monismo teórico. $\mathrm{O}$ argumento da eliminação é antipódico à proposta de Feyerabend (1999a, p. 107-8) de considerar "imprudente desistir de uma teoria porque se revela incompatível com resultados observacionais ou porque sofre de dificuldades internas".

Com função destacada nas obras de importantes teóricos sociais, o argumento da eliminação pretende pôr fim à proliferação por considerá- 
-la, como pensa Durkheim, fruto da variedade de visões filosoficamente fomentadas. Advogando que Durkheim "deposita mais confiança na infirmação que na confirmação", Schmaus (1994, p. 90) chega, de modo questionável, a aproximá-lo de Popper. Na verdade, Durkheim confere função decisiva ao argumento da eliminação por acreditar que a refutação das outras teorias é crucial em virtude de permitir indiretamente verificar a preferida, apresentada como a única capaz de sobreviver aos crivos empíricos. Longe de se manterem como contrapontos críticos à vencedora, as teorias consideradas refutadas devem ser, no entender de Durkheim, definitivamente postas de lado.

Diante dos insuperáveis impasses explicativos, e principalmente da impossibilidade de excludentes ou conflitantes teorias serem todas verdadeiras, o pesquisador social acredita que o argumento da eliminação lhe confere autoridade epistêmica para afastar as explicações contrariadas pelos fatos e para justificar indiretamente a concessão de monopólio à teoria predileta. Se a opção por determinada teoria se baseia decisivamente na exclusão de alternativas conflitantes com a evidência fatual, então o método empírico se caracteriza pela função primária de eliminar teorias e pela secundária de referendar a teoria preferida supondo-a em correspondência com os fatos. A confiança epistêmica no argumento da eliminação se assenta no pressuposto de que as teorias descartadas, junto com a que sobreviveu aos controles empíricos, esgotam as possibilidades explicativas sobre o que se investiga. Supondo-se peremptórias as evidências contra as teorias formuladas, a nova é proposta como a única admissível.

llustrando de modo exemplar o combate à proliferação por meio do argumento da eliminação, Durkheim em Le Suicide arrola os fatores extrassociais - com destaque para clima, raça, hereditariedade, neurastenia, insanidade etc. - que têm sido invocados para explicar as variáveis taxas de suicídio encontradas em diferentes sociedades. Estados psicopáticos podem predispor ao suicídio, mas não são causas suficientes. As explicações baseadas em fatores extrassociais são afastadas a favor da teoria de que o suicídio tem causas exclusivamente sociais. A entronização da explicação 
de tipo social e a eliminação das alternativas é a maneira encontrada por Durkheim para acabar com a diversidade explicativa. Os defeitos das teorias existentes são indigitados por Durkheim com a finalidade de afastá-las em definitivo e substituí-las por uma explicação apresentada como a única capaz de sobreviver aos crivos empíricos. Antes de apresentar sua teoria como apoiada em evidências empíricas taxativas, Durkheim afasta as teorias antes formuladas, em especial as que procuram lidar com a constituição orgânico-psíquica dos indivíduos ou com fatores da ambiência física.

Sendo determinado por causas sociais, o suicídio é residualmente provocado por fatores situados no plano da existência individual. Tal tese seria confirmada pela constatação de que a taxa de suicídio (ou taxa de variação) em dada sociedade permanece surpreendentemente constante de ano para ano. No entender de Durkheim (1967, p. 222-223), tal constância não teria como ser explicada se a taxa de suicídio dependesse de idiossincrasias, volições e propensões individuais que, por serem altamente variáveis e circunstanciais, só exibem casualidade refratária à investigação científica. É importante ter presente que, para Durkheim, um fato (caracterizado como) social só pode ser explicado recorrendo-se a outro fato social (anterior), jamais a outro tipo de fato(r) como, por exemplo, o biológico ou o psicológico.

Em virtude de privilegiar o observável, de conceber e abordar o social como chose, Durkheim (1967, p.4) define suicídio sem fazer qualquer referência à intenção "considerada coisa muito íntima para poder ser apreendida de fora". Deixa de lado a problemática da intencionalidade e da significatividade da ação humana declarando que são empiricamente inacessíveis. Com isso, rechaça teorias sociais que enfatizam o sentido subjetivo e a natureza propositada da ação humana. Durkheim recorre ao argumento da eliminação convencido de que elencar, ainda que de modo sumário, os defeitos das teorias alternativas à sua o dispensam de ter de admitir a possibilidade de conterem algo de verdadeiro. Assim procedendo, Durkheim faz uso do argumento da eliminação de uma forma que impede que a pesquisa social venha a avançar explorando uma pensável complementaridade explicativa entre as teorias disponíveis e a nova. Por 
mais que se justifique o afastamento definitivo das alteridades, Durkheim negligencia que a teoria preferida é submetida a crivos metodológicos que ensejam apenas pareceres parciais e provisórios.

O risco de reducionismo é grande quando se considera desnecessária a busca de complementaridade entre os diferentes tipos de fatores, e as várias ciências, na explicação de um fenômeno complexo como o suicídio. Representando uma maneira questionável de lidar com os desafios da proliferação, o modelo monocausal de explicação leva Durkheim (1967, p. 139) a sustentar que "em cada grupo social há uma tendência específica ao suicídio, que não se pode explicar nem através da constituição orgânico-psíquica dos indivíduos nem através da natureza do meio físico; portanto, por eliminação, depende necessariamente de causas sociais e constitui por si só um fenômeno coletivo".

Sendo considerado ocioso construir teorias que levem em consideração outras modalidades de fatores, como os psicológicos ou os biológicos, a conquista de resultados explicativos é exclusiva a uma ciência e a uma de suas teorias. $O$ combate à proliferação que acredita que a eventual detecção de erros nas outras teorias infunde, per se, poder explicativo a uma teoria, a remanescente, que presume que a (suposta) falsidade das rivais equivale a uma forma indireta de estabelecer a verdade da teoria predileta, é equivocado porque inexistem boas razões para se decretar que a teoria acolhida seja a última cogitável, a única sustentável por fatos passados e futuros.

Atribuir ao social poder causal exclusivo na produção de determinados tipos de fato - como faz Durkheim - é uma maneira inapropriada de combater a proliferação na medida em que afasta in limine, com base em evidências empíricas parciais, a possibilidade de outros fatores - como, por exemplo, os desequilíbrios psicopatológicos e as neuropatias - também contribuírem para a ocorrência do suicídio. Esse "imperialismo" do fator social impede de modo apriorístico a expansão do raio explicativo em virtude de a teoria preferida ser monocausal e monopolista. Nos estudos dos fenômenos sociais, as críticas às postulações de exclusividade teórica são procedentes, uma vez que fatores psicológicos e genéticos podem 
se associar, mesmo que não sejam as causas primárias das variações nas taxas de suicídio, aos deflagradores sociais do suicídio.

Durkheim (1968, p. 33-34) também faz uso do argumento da eliminação quando, no estudo da religião, sustenta que não deveria ser definida pela noção de "sobrenatural" nem pela de "divindade". Pressupondo secularização e contraposição a um mundo natural governado por leis impessoais, o conceito de sobrenatural para Durkheim só pôde se formar recentemente. A noção de Deus também não é vista como essencial à caracterização da religião por haver casos reconhecidos, como o do budismo, em que a figura de Deus está ausente. Repelindo tanto a teoria animista da religião, defendida especialmente por Edward Taylor e Herbert Spencer, quanto a naturalista adotada principalmente por Max Müller, Durkheim (1968, p. 13) concebe a religião como "uma coisa eminentemente social, uma vez que as representações religiosas são representações coletivas que exprimem realidades coletivas". Durkheim descarta as outras teorias por "insuficiência indutiva" entendida como incapacidade de explicar, na sua totalidade, o conjunto dos fenômenos religiosos. $\mathrm{O}$ "argumento da ilusão" de Marx (1970, p. 131) - para o qual a religião é o ópio do povo - é também rejeitado por Durkheim em virtude de provocar o desvanecimento daquele que deveria ser o objeto de uma ciência da religião. Sendo um fato social, ao qual se atribui status ontológico de chose, a religião não pode ter sua existência classificada de especiosa.

A eliminação de alternativas, como a levada a cabo por Durkheim, pode provocar - como ressalta Feyerabend - diminuição de conteúdo empírico e impedir o acesso a fatos cuja descoberta só poderia ocorrer com a ajuda de teorias alternativas. Contra o argumento da eliminação, é também importante reconhecer a possível proficuidade da proliferação de tipo interdisciplinar capaz de evitar, por exemplo, que seja liminarmente afastada a hipótese de componentes psicológicos e biológicos terem, em articulação com fatores sociais, poder causal, ainda que menor ou residual, no desencadeamento do suicídio. É pouco defensável o duplo monopólio 
perseguido por Durkheim - a uma teoria (a sua) e a uma ciência (a sociologia) - no estudo de fenômenos como o suicídio.

O amplo emprego do argumento da eliminação conflita com a recomendação de Feyerabend (1977a, p. 14) de se evitar considerar "a pluralidade de teorias uma etapa preliminar do conhecimento a ser, em algum momento no futuro, substituída pela Única Teoria Verdadeira". O descarte de teorias aposta na avaliação peremptória na medida em que supõe que as afastadas junto com a nova, a pretensamente verificada, exaurem o conjunto das possíveis candidatas à melhor explicação. A constatação de que uma teoria desbancou as alteridades permite, quando muito, saber que até aquele momento é a melhor por não ter sido ainda refutada. A identificação das debilidades das teorias rivais não impede que as da teoria escolhida venham a ser detectadas à luz de novas evidências.

A obsessão do pesquisador social por afastar as teorias alternativas às vezes o leva a acusá-las de ideológicas, como reiteradamente faz Marx. 0 reducionismo - para o qual há um tipo de fator determinante, por exemplo, o econômico, com base no qual são explicados os outros tipos de fato da vida social - tem sido igualmente empregado para combater a proliferação. Torna-se desnecessário dar atenção a outras teorias, a outros domínios da pesquisa, em virtude de se debruçarem sobre epifenômenos. O reducionismo professado pelo marxismo encara os fatores extraeconômicos como variáveis dependentes tornando de secundária importância a elaboração de explicações mistas resultantes de enfoques interdisciplinares. Descartando, por exemplo, as várias concepções de Estado até então formuladas, Marx (1970, p. 134), em um momento subsequente, critica o próprio Estado em virtude de estar convencido de que "a própria moderna realidade político-social deve ser submetida à crítica". O Estado precisa ser extinto por ser uma instituição com a exclusiva função de repressão e dominação de uma classe social sobre as outras. Em nome da busca da cientificidade, 0 reducionista, assim como o monopolista, desqualifica como "filosófica" a visão de que uma teoria identifica apenas os fatos que a trama de sua rede 
linguístico-epistêmico-ontológica consegue reter e a de que uma teoria precisa ser testada à luz (dos fatos) de outra.

Desponta inócua a proposta de Feyerabend (1970, p. 310) de "reter e inventar teorias contrafactuais" caso se leve em conta que fazem parte do quadro geral de proliferação característico do evolver das ciências sociais. Diferentemente do que supõe Feyerabend, a diversidade explicativa não tem feito com que, "os ingredientes ideológicos de nosso conhecimento e, mais especificamente, de nossas observações sejam descobertos com a ajuda de teorias refutadas por eles". Nos domínios em que a proliferação se mantém constante, o conselho feyerabendiano de conservar o velho e criar o novo como alteridades críticas à teoria predileta fica longe de promover os efeitos benéficos apregoados. Na falta de eficazes dispositivos epistêmicos de seleção de teoria, a proliferação se reproduz indefinidamente.

A observação de Feyerabend (1981b, p. 139) de que mesmo "em uma competição justa, uma ideologia, em parte por acidente e em parte porque se lhe devota uma maior atenção, pode obter êxitos e superar suas rivais" se aplica em parte às disciplinas sociais e mais ainda o que afirma em continuação: "isso não significa, porém, que as rivais vencidas careçam de mérito e que tenham deixado de ser capazes de contribuir para o conhecimento, significa apenas que temporariamente perderam o gás; isto porque podem retornar e derrotar seus vencedores, como serve de excelente exemplo a filosofia do atomismo". O fato de nas disciplinas sociais as tentativas de formação de monismos teóricos e monopólios explicativos terem uma história marcada pelo insucesso não se presta a arrimar a tese de que a mais ampla testagem das teorias requer que cada uma também seja avaliada por fatos só apreensíveis por rivais. Falta a demonstração de que a crítica ampla e diuturna deixa de poder ser posteriormente exercitada sem a teoria eliminada. Em contraposição, eliminacionistas como Durkheim estão equivocados quando pensam que a teoria sobrevivente pode ser eximida de aferição continuada por terem sido refutadas as alternativas. 


\section{A infecundidade das duplicações explicativas: um estudo de caso}

Há na história das ciências sociais casos em que duas teorias sobre o mesmo objeto de estudo afrontam impasses explicativos refratários a tentativas de aplicação do argumento da eliminação. A despeito de se debruçarem sobre um mesmo domínio de fatos, dão origem a teorias cujos resultados finais excludentes dificultam o estabelecimento de méritos relativos. Mesmo se pretendendo empíricas, são pesquisas que chegam a conclusões diametralmente opostas, de tal modo que o intento de promover o intercâmbio crítico esbarra no obstáculo de se organizarem em torno de pressuposições absolutas que fazem com que cada uma se transforme em uma mônada explicativa. Fica-se, assim, muito longe da situação idealizada por Feyerabend em que uma teoria é fundamental para a aferição da outra. Se cada teoria apreende apenas os fatos detectáveis por seus filtros, disso resulta que, nas disciplinas sociais, os defensores de uma teoria deixam de vislumbrar importância nos fatos localizados por alteridades.

Explicações antagônicas sobre um mesmo e singular objeto de estudo evidenciam inexistir complementaridade empírica, ou mesmo comensurabilidade teórica e observacional, entre elas. Na verdade, são estudos cujas conquistas explicativas se defendem tanto de avaliações isoladas quanto de comparativas. llustraremos isso recorrendo ao caso emblemático de dois famosos estudos que, apesar de se devotarem a uma mesma comunidade, chegam a "retratos sociais" inconciliáveis. Debruçados sobre o vilarejo de Tepoztlan, os trabalhos de Redfield e de Lewis parecem discorrer sobre mundos sociais diferentes. A pesquisa realizada por Redfield, de 1926 a 1927, foi seguida, não muito tempo depois, por outra de Lewis com conclusões diametralmente opostas. Os resultados alcançados pela reconstrução de Redfield colocam em destaque os fortes elementos promotores da integração na comunidade: 
O bilinguismo essencial da população reflete o equilíbrio no plano da cultura entre os elementos índio e europeu; a cultura não é aborígine nem espanhola, mas uma íntima integração de ambas - é mexicana [...] A integração de certos elementos europeus com características índias está completa [...] estando envolvidos elementos índios sobreviventes e certos elementos europeus, a integração é completa (REDFIELD, 1930, p. 30,50).

Sem que Tepoztlan tivesse passado por mudanças significativas, in loco capturáveis, Lewis desenvolve uma igualmente importante pesquisa, de 1943 a 1948, na qual chega a conclusões que se contrapõem às de Redfield: em Tepoztlan predominam pressões e tensões. Esmiuçando o mesmo espaço comunitário, Lewis obtém resultados que não se prestam, contrariando a tese das vantagens epistêmicas da proliferação, a "testar" os alcançados por Redfield. A teoria de que a vida em Tepoztlan não é feliz nem satisfatória não é mais bem avaliada recorrendo-se aos fatos específicos pretensamente só apreendidos pela óptica da teoria rival. O mesmo se pode dizer da tese oposta. Nesse caso, as teorias despontam incomensuráveis sem que tenha ocorrido algo que lembre a situação de descontinuidade explicativa descrita por Kuhn: mudando os paradigmas, o próprio mundo muda, de tal modo que depois de uma revolução os cientistas estão respondendo a um mundo diferente. No caso de Tepoztlan, não se aplica a tese de Kuhn (1970, p. 183) de que "embora o mundo não mude com uma mudança de paradigma, quando isso ocorre o cientista trabalha em um mundo diferente".

Merece destaque o comentário de Lewis de que realizou sua pesquisa com o propósito inicial de dar continuidade à de Redfield, mas que profundas diferenças nos modos de apreender e compreendera realidade social de Tepoztlan rapidamente começaram a aparecer. As divergências de Lewis com Redfield são assim resumidas: minhas descobertas enfatizam o individualismo subjacente às instituições e ao caráter de Tepoztlan, a falta de cooperação, as tensões entre os vilarejos do mesmo município, as cismas no interior do vilarejo e a presença abrangente do medo, da inveja e da desconfiança. Seria 
fundamental entender como pôde Lewis ter pintado um quadro antipódico - no qual a comunidade desponta infeliz e repleta de medo, de inveja e desconfiança - sem que a realidade estudada tivesse sofrido profundas transformações, sem que o estudo anterior tivesse se mostrado anacrônico ou errado à luz de novas evidências. O diagnóstico de que observaram aspectos diferentes da comunidade por se valerem de distintos óculos teóricos é pouco favorável à defesa da proliferação se as lentes usadas por Redfield para enxergar o que singulariza Tepoztlan foram descartadas por Lewis.

De um modo que gera a dúvida de se está se reportando à mesma comunidade, Lewis (1951, p. 428-9) assim descreve as profundas diferenças entre as conclusões de sua pesquisa e as alcançadas por Redfield: "a impressão deixada pelo estudo de Redfield sobre Tepoztlan é a de uma sociedade relativamente homogênea, isolada, com um funcionamento suave, bem integrada formada por pessoas bem ajustadas e contentes; sua descrição do vilarejo tem um teor rousseauniano, que desconsidera sutilmente as evidências de violência, perturbação, crueldade, pobreza, doença, sofrimento e desajustamento; pouco ficamos sabendo da pobreza, dos problemas econômicos e dos cismas políticos; em todo seu estudo, encontramos uma ênfase nos fatores cooperativos e unificadores na sociedade Tepoztlan".

O "caso de Tepoztlan" na história das ciências sociais é representativo porque mostra que se cada teoria (social) desvela apenas os fatos que se enquadram em sua moldura, como propala Feyerabend, o desfecho tende a ser o entrincheiramento das teorias e não a complementaridade capaz de propiciar a testagem de uma teoria por meio de outra(s). O que se costuma comprovar é que aquilo que uma Escola do pensamento social invoca como fato, como trama fatual, costuma ser ignorado por outra. Isso ajuda a entender por que as divergências entre Lewis e Redfield não alimentam um profícuo jogo entre mesmo e outro; e também porque não se prestam a montar o teatro metodológico defendido por Feyerabend em que uma teoria e seus fatos e outra teoria e seus outros fatos se entregam a uma avaliação recíproca. 
Os estudos dedicados a Tepoztlan deixam claro que são consideráveis as dificuldades de comparação até mesmo quando está apenas em questão determinar qual a melhor dentre duas explicações sobre um mesmo objeto. Fica-se longe de comprovar que uma teoria é sempre capaz de contribuir para a avaliação de outra. Inexiste "interdependência fatual" se uma teoria identifica um "quadro social" composto de estados de coisas cuja existência é negada por outra. Sem a subsistência de uma base empírica compartiIhada, ao menos parcialmente, tanto a duplicação quanto a proliferação de teorias geram insulamento explicativo. Na falta de critérios epistêmicos de avaliação compartilhados, a decisão a favor de uma das teorias acaba sendo tomada com base na predominância de motivos axiológicos ou ideológicos.

Supondo-se que o que tinha de ser levado em consideração na obra de Redfield o foi por Lewis, as aferições críticas a que foram submetidas as duas teorias se revelaram impotentes para arbitrar suas divergências. Como se fossem sistemas explicativos autocontidos, as teorias de Redfield e Lewis se mostraram impermeáveis a comparações críticas capazes de estabelecerem méritos relativos. No caso de não se ter como cotejar as teorias parte por parte fica difícil determinar em que uma é superior à outra. Se teorias rivais, mesmo que refutadas, têm condições de suprir fatos com potencial de avaliar a teoria preferida, como advoga Feyerabend, cumpre explicar por que o simples confronto crítico enfrenta percalços, como o exemplifica o caso Tepoztlan, nas disciplinas sociais. Os modos com que Redfield e Lewis reconstroem a vida social de Tepoztlan ilustram que a duplicação teórica é improfícua nas situações em que fracassam os intentos de hierarquizar o valor explicativo das concorrentes por meio da arbitragem das divergências.

Distinguindo-as das background assumptions, das teorias gerais da realidade, Gouldner (1970, p. 31) apresenta as domain assumptions como metafísicas circunscritas. Quando concernem o ser humano e a vida social "podem incluir, por exemplo, disposições a acreditar que os homens são racionais ou irracionais, que a sociedade é precária ou essencialmente estável, que os problemas sociais se corrigirão sem a intervenção plane- 
jada". As diferentes domain assumptions abraçadas por Redfield e Lewis explicam suas conclusões diametralmente opostas.

Bendix e Berger (1959, p. 92-118) chamam a atenção para o fato de que as disciplinas sociais estão infestadas de paired concepts. Um bom exemplo é o dualismo cooperação e conflito; com base nele se formam as insanáveis divergências entre as teorias de Redfield e Lewis. Na história das ciências sociais, muitos dos conflitos teóricos entre Escolas decorrem de reconstruírem os processos e as estruturas sob a óptica da integração/cooperação ou da disputa/conflito. Teorias que se formam a partir de dicotomias se mostram incapazes de contribuir para a avaliação recíproca. É controverso que subsista incomensurabilidade entre a mecânica clássica e a teoria da relatividade, como defende Kuhn, mas a proliferação e a duplicação de teorias sociais as tornam incomensuráveis em termos metodológicos, semânticos e ontológicos.

Longe de confirmar a interdependência metodológica e ontológica entre as teorias, a diversidade explicativa nas disciplinas sociais contraria a pregação de Feyerabend (1977a, p. 14) de que "só pode ser um bom empirista quem estiver preparado para trabalhar com muitas teorias alternativas e não com um único ponto de vista e a "experiência"”. Os tipos de embate travados, por exemplo, entre as teorias sociais construídas com base em uma metodologia de tipo causal e as que se assentam em uma metodologia de tipo compreensivo geram proliferação e polarização que desembocam em um tipo de contraposição igualmente incapaz de promover formas mais aprofundadas de testagem. Entre essas Escolas jamais se estabeleceu um tipo de intercâmbio crítico fundado na crença de que os fatos identificados por alteridades podem contribuir direta ou indiretamente para testar uma teoria. As disciplinas sociais não tiram proveito da história marcada por disputas metodológicas e menos ainda dos renitentes debates ontológicos, como o representado pela contraposição entre holismo/coletivismo e individualismo metodológico.

Uma óptica com domain assumptions incompatíveis com as de outra, não desperta a atenção (da outra) para os (supostos) fatos que (só ela) identifica. Teorias que abraçam pressuposições absolutas excludentes - uma se volta, por 
exemplo, para a finalidade e a intencionalidade da ação e a outra só admite o tipo de investigação confinado ao overt behavior - têm-se mostrado incapazes de problematizar suas diferenças. Na história das ciências sociais tem avançado pouco o debate ontológico a respeito de se coletivos e classes sociais têm ou não vida própria, se determinam o que pensam e fazem os indivíduos. Mesmo sendo contrapontos críticos umas das outras, as teorias sociais não têm como testar umas às outras se não forem individualmente testáveis. Mesmo possuindo as condições favoráveis à colocação em prática da recomendação de se recorrer a todo tipo de alteridade, as Escolas propendem ao enclausuramento epistêmico-ontológico. O tipo de avaliação crítica que, por exemplo, o behaviorismo faz da psicanálise é improfícuo porque rejeita as pressuposições absolutas que a singularizam. As pesquisas sociais se reportam a alteridades porque não têm como ignorá-las, não porque dão acesso a outros conteúdos empíricos propiciadores de formas mais eficazes de avaliação metodológica. A inexistência de um "supremo tribunal da experiência" nas disciplinas sociais não demonstra que os múltiplos e descentralizados julgamentos ensejem meios e modos mais amplos de testagem.

O conselho de Feyerabend (1981a, p. 105) - "inventem e elaborem teorias que sejam incompatíveis com o ponto de vista aceito por mais que se mostre altamente confirmado e seja amplamente aceito" - não tem como ser seguido nas disciplinas sociais porque nenhuma teoria, dentre as já criadas, conseguiu granjear ampla aceitação. A tese de Feyerabend (1993, p. 5) de que "hipóteses que contradizem teorias bem confirmadas proporcionam evidência impossível de ser obtida de outro modo" não encontra respaldo na pesquisa social em razão de várias serem as teorias excludentes, mas nenhuma bem confirmada, nenhuma oferecendo evidência crucial para avaliar outra.

$O$ aspecto de se organizarem em torno de matrizes filosóficas inconciliáveis ajuda a entender por que é difícil testar uma teoria social à luz dos fatos que ela mesma identifica e mais ainda atentando para fatos que só outras teorias de outras correntes (supostamente) desvelam. Os abismos explicativos permanecem insuperáveis, o intercâmbio crítico inviabilizado, 
se uma teoria abraça pressuposições absolutas que priorizam, por exemplo, o sentido subjetivo da ação, à maneira de Weber (1978, p. 4), ou a finalidade da ação, como faz Mises (1962, p. 34), e outras se mostram defensoras de abordagens quantofrênicas ou testomaníacas, como as caracteriza Sorokin (1965, p. 51,103), que intentam adstringira pesquisa ao quantificável, ao passível de teste ou mesmo ao comportamento observável.

Visto que a pregação feyerabendiana em prol da multiplicação de ópticas só pode ter como alvo as ciências naturais, cabe saber em que a proliferação as beneficiaria em termos explicativos, preditivos ou instrumentais. Se a descoberta e a descrição de fatos são teoricamente dependentes, as disciplinas sociais têm-se revelado incapazes de tirar proveito da diversidade explicativa que abrigam sem que se possa creditar isso à falta de acuidade de seus praticantes para reconhecerem ser fecundo cotejar a teoria preferida não só com a classe de fatos (ou enunciados observacionais) que ela identifica como também com os fatos apreensíveis pelas alteridades.

Justifica-se pensar que as diferenças entre as teorias sociais são costumeiramente "arbitradas" com base em preferências axiológicas e ideológicas, uma vez que a elas não se tem como aplicar o critério pragmático do sucesso preditivo, que teria permitido às teorias das ciências naturais, segundo Hesse (1978, p. 4), filtrar valores. Sendo determinada explicação escolhida por seu poder instrumental, é cabível supor que isso se deva ao apoio que recebe dos fatos, de tal maneira que se tornaria desnecessário dar atenção a alteridades. Nesse caso, a falta de poder instrumental seria decisiva para a proliferação e faria com que as teorias sociais se mantivessem insubmissas a mecanismos de seleção abdutiva.

A peculiaridade de muitos fatos sociais de se apresentarem com uma compreensão de si mesmos dificulta a testagem em geral antes mesmo de se poder discutir a possibilidade de aferição recíproca das teorias. A assunção de pressuposições absolutas excludentes faz com que nas ciências sociais se perenize um estado de divergência "fundacional" - retratado por impasses metodológicos, ontológicos, axiológicos e ideológicos - semelhante ao que pode ser encontrado na filosofia. Se as diferenças entre as teorias 
resultam da adesão a excludentes pressuposições absolutas - como, por exemplo, as físicalistas e as "intencionalistas" - pouca serventia tem uma teoria apontar para outra a existência de outros fatos. A opção por uma metodologia compreensiva, voltada para a apreensão do sentido subjetivo da ação social, leva a destacar um tipo de fato que para o fisicalismo sequer existe. Se o fato social não é mera ocorrência ou recorrência, uma vez que apresenta uma compreensão de si mesmo, isso não é captado pelo radar fisicalista; se o fosse, seria considerado irrelevante. Por essa razão, o sentido subjetivo da ação é desqualificado por sua captação envolver, nas palavras de Neurath (1973, p. 357), colocar “a imersão empática no lugar da ciência [...] para tal atividade poética não há teste ou controle empírico, uma vez que não pertence à explicação científica".

Nenhuma teoria social se submeterá a crivos apontados por outra se isso envolver abrir mão dos critérios metodológicos e compromissos ontológicos que a singularizam. Se algum fato apreendido com exclusividade por uma teoria tiver o poder de refutar outra, será ignorado caso se vincule a um conjunto de pressuposições absolutas diferentes das que organizam a teoria preferida. Caso ocorra, a identificação de diferentes fatos por diferentes teorias sociais leva ao isolamento, não à avaliação interdependente. Sem critérios que definam de que modo, em que extensão, uma teoria é efetiva alteridade à preferida, pode-se fazer apenas a constatação trivial de que teorias - como a que vincula a ética protestante ao espírito do capitalismo e a que encara a religião como epifenômeno de determinantes econômicos - são discrepantes, mas não que uma sirva para aprofundar a testagem da outra.

Sendo a óptica alternativa fornecida até pelo saber especulativo, como acredita Feyerabend, então a princípio tudo pode testar tudo. Precisando também ser avaliada por conteúdos explicativos produzidos fora de seus confins, a ciência não tem como avaliar a si mesma de modo pleno e autárquico. Mesmo porque precisa sempre se certificar de estar levando em consideração explicações encontráveis fora de suas fronteiras. 
Apesar de ser uma atividade marcada pela capacidade de se autocorrigir, a ciência perde a autoridade para, sozinha, chancelar os próprios resultados:

Por mais que uma teoria pareça refletir fidedignamente os fatos, por mais universal que seja seu uso [...] sua adequação fatual só pode ser afirmada depois de ter sido confrontada com alternativas cuja invenção e desenvolvimento detalhado devem preceder qualquer afirmação final sobre o sucesso prático e a adequação factual. Esta é a justificação metodológica em prol de uma pluralidade de teorias (FEYERABEND, 1977a, p. 15).

Levando às últimas consequências o Princípio da Proliferação, todos os fatos importantes para a avaliação de uma teoria só se tornam apreensíveis quando todas as alternativas explicativas possíveis tiverem sido localizadas e produzidas. O processo de avaliação nunca chega ao fim porque novos fatos dependem da invenção de novas teorias, de tal modo que passa a ser vital a ars inveniendi sobre a qual não se tem controle em virtude de inexistir uma lógica da criação. A metodologia se torna dependente da heurística se parte fundamental da testagem de uma teoria precisa ser feita com base em fatos que só podem ser desvelados por outra teoria, muitas vezes, ainda por ser criada. Permanece inconclusivo o processo de avaliação metodológica se a ars probandi fica a reboque da ars inveniendi, se a avaliação exaustiva de uma teoria só ocorre depois de terem sido inventadas todas as teorias possíveis.

\section{Considerações finais}

Diferentemente do que pressupõe o Princípio da Proliferação, as teorias sociais não funcionam como alteridades umas das outras porque nenhuma dá acesso, de modo amplamente reconhecido, a outros fatos. Se por um lado um sobrevoo da história das ciências naturais indica ser discutível que teorias tenham de levar em conta fatos que (supostamente) 
só são apreensíveis por alteridades, a proliferação subsistente nas disciplinas sociais mostra que está longe de contribuir para tornar as teorias mais testáveis. Entre a tentativa de eliminar teorias rivais com a esperança de se ficar com a verdadeira e a realidade da proliferação irrefreável, as disciplinas sociais enfrentam sérias dificuldades para simplesmente escolher a melhor dentre as candidatas à boa explicação.

As ciências sociais mostram que a testagem abrangente e eficaz de uma teoria independe de se ter acesso a alteridades, que apontam para a existência de outros fatos. Em casos específicos, a diversidade explicativa pode se revelar importante para fomentar o intercâmbio crítico. No entanto, a variedade de teorias tem levado ao entrincheiramento em razão de os fatos reputados fundamentais por um ismo sequer serem reconhecidos por outro. Feyerabend prega que se recorra diuturnamente a teorias alternativas sem fazer referência às ciências sociais no interior das quais sempre existiu um disputado jogo, pouco proveitoso, entre explicações rivais. As disciplinas sociais deixam de oferecer a comprovação de que, inexistindo fatos universalmente apreensíveis, passam a ser fundamentais - para provocar a refutação de uma teoria - os fatos que uma teoria, e só ela, pode indigitar para outra.

Feyerabend deixa de oferecer uma regra do método ou um mecanismo seletivo por meio do qual se possa promover a rejeição e eliminação de ideias, de tal modo que, seguindo à risca seu receituário, prevalece um processo de acumulação crescente de teorias, todas colocadas em discussão em todos os domínios do saber sem que se justifique banir qualquer uma delas. É precisamente a falta de um critério de descarte que ajuda a entender por que as tantas teorias sociais coexistem indefinidamente uma ao lado da outra, ou uma contra a outra, levando os pesquisadores a procurarem acabar com a proliferação por meio do argumento da eliminação. Tomando as ciências sociais como campo de exemplificação, a falta de comprovação das decantadas vantagens epistêmicas da proliferação tem feito com que se mantenha hegemônica a aplicação do argumento da eliminação. 


\section{Referências}

AMSTERDAMSKI, S. Between Experience and Metaphysics. Trad de P. Michalovoski, Dordrecht: D. Reidel Publishing Company, 1975.

BENDIX, R.; BERGER, B. Images of Society and Problems of Concept Formation in Sociology. In: GROSS, L. (org.). Symposium on Sociological Theory. Evanston: Row, Petersen \& Co., 1959.

BOTTOMORE, T. B. Sociology: A Guide to Problems and Literature. Nova lorque: Vintage Books, 1972.

BRAITHWAITE, R. B. Scientific Explanation. Cambridge: Cambridge University Press, 1968.

COLLINGWOOD, R. G. An Essay on Metaphysics. Oxford: Clarendon Press, 1948.

DURKHEIM, É. Le Suicide. Paris: Presses Universitaires de France, 1967.

DURKHEIM, É. Les Formes Élementaires de la Vie Religieuse. Paris: Presses Universitaires de France,1968. https://doi.org/10.14361/9783839413272-038

FEYERABEND, P. Explanation, Reduction, and Empiricism. In: FEIGL, H. \& MAXWELL, G. (org.). Scientific Explanation, Space and Time. Minneapolis: University of Minnesota Press, 1962.

FEYERABEND, P. Problems of Empiricism. In: COLODNY, R. (org.). Beyond the Edge of Certainty. Englewood Cliffs: Prentice-Hall, 1965.

FEYERABEND, P. Problems of Empiricism, Part. II. In: COLODNY, R. G. (org.). The Nature and Function of Scientific Theories. Pittsburgo: University of Pittsburg Press, 1970.

FEYERABEND, P. Science in a Free Society. Londres: Verso, 1978.

FEYERABEND, P. How to be a Good Empiricist - A Plea for Tolerance in Matters Epistemological. In: NIDDITCH, P. H. (org.). The Philosophy of Science. Oxford: Oxford University Press, 1977a.

FEYERABEND, P. Consolations for the Specialist. In: LAKATOS, I \& MUSGRAVE, A. (org.). Criticism and the Growth of Knowledge. Cambridge: Cambridge University Press, 1977b.

FEYERABEND, P. Reply to Criticism. Comments on Smart, Sellars and Putnam. Realism, Rationalism and Scientific Method: Philosophical Papers. Cambridge: Cambridge University Press, 1981a. Vol. 1. https://doi.org/10.1017/ cbo9781139171526.007 
FEYERABEND, P. Introduction: Proliferation and Realism as Methodological Principles. Realism, Rationalism and Scientific Method: Philosophical Papers Cambridge: Cambridge University Press, 1981b. Vol. 1. https://doi.org/10.1017/ cbo9781139171526.009

FEYERABEND, P. Two Models of Epistemic Change: Mill and Hegel. Philosophical Papers. Cambridge: Cambridge University Press, 1986. Vol. 2.

FEYERABEND, P. Farewell to Reason. Londres: Verso, 1987.

FEYERABEND, P. Against Method. Londres: Verso, 1993.

FEYERABEND, P. Killing Time. Chicago: The University of Chicago Press, 1995.

FEYERABEND, P. Outline of a Pluralistic Theory of Knowledge and Action. In: PRESTON, J. (org.). Knowledge, Science and Relativism. Philosophical Papers 1. Cambridge: Cambridge University Press, 1999a. https://doi.org/10.1017/ soo31819101210110

FEYERABEND, P. Knowledge without Foundations. In: PRESTON, J. (org.) Knowledge, Science and Relativism. Philosophical Papers 1. Cambridge: Cambridge University Press, 1999b. https://doi.org/10.1017/s0031819101210110 GODFREY-SMITH, P. Theory and Reality. Chicago: The University of Chicago Press, 2003.

GOETHE, J. W. Maxims and Reflections. Trad. de Elisabeth Stopp. Londres: Penguin, 1998.

GOULDNER, A. The Coming Crisis of Western Sociology. Nova lorque: Basic Books, 1970. https://doi.org/10.3817/0970006338

HABERMAS, J. A Positivistically Bisected Rationalism. The Positivist Dispute in German Sociology. Londres: Heinemann, 1977.

HESSE, M. 'Theory and value in the social sciences'. In: HOOKWAY; PETTIT (org.). Action \& interpretation. Studies in the Philosophy of the Social Sciences. Cambridge: Cambridge University Press, 1978.

JARVIE, I. C. Thinking about Society: Theory and Practice. Dordrecht: D. Reidel Publishing Company, 1986.

KUHN, T. The Structure of Scientific Revolutions. In: NEURATH, O. CARNAP, R. \& MORRIS, C. (org.). Foundations of the Unity of Science. Chicago: The University of Chicago Press, 1970. Vol. II. 
LAKATOS, I. Falsification and the Methodology of Scientific Research Programmes. In: LAKATOS, I.; MUSGRAVE, A. (org.). Criticism and the Growth of Knowledge. Cambridge: Cambridge University Press, 1977.

LAUDAN, L. Beyond Positivism and Relativism. Boulder: Westview Press, 1996.

LEWIS, O. Life in a Mexican Village: Tepoztlan Restudied. Urbana: University of Illinois Press, 1951. https://doi.org/10.1126/science.114.2966.470-a

LUKES, S. Emile Durkheim. His Life and Work: a Historical and Critical Study. Middlesex: Penguin Books, 1977.

MARX, K. Critique of Hegel's 'Philosophy of Right'. Trad. de Annette Jolin e Joseph O'Malley. Cambridge: Cambridge University Press, 1970.

MILL, J. S. On Liberty. Ontario: Batoche Books Limited, 2001.

MILL, J. S. A System of Logic. Londres: Longmans Green and Co. 1949.

MISES, L. von. The Ultimate Foundation of Economic Science. Princenton: D. Van Nostrand Co., 1962.

NEURATH, O. Empiricism and Sociology. Editado por Marie Neurath e R. Cohen. Dordrecht: D. Reidel Publishing Company, 1973. https://doi.org/10.1007/97894-010-2525-6

POINCARE, H. Science et Méthode. Paris: Ernest Flammarion Éditeur, 1912.

POPPER, K. R. Normal Science and its Dangers. In: LAKATOS, I.; MUSGRAVE, A. (org.). Criticism and the Growth of Knowledge. Cambridge: Cambridge University Press, 1977.

POPPER, K. R Realism and the Aim of Science. Londres: Routledge, 1996.

PRESTON, J. Feyerabend: Philosophy, Science and Society. Cambridge: Polity Press, 1997.

PRESTON, J. Paul Feyerabend. In: ZALTA, E. (org.). The Stanford Encyclopedia of Philosophy. Disponível em: https://plato.stanford.edu/archives/win2016/ entries/feyerabend/.

PUTNAM, H. Degree of Confirmation and Inductive Logic. The Philosophy of Rudolf Carnap. Illinois: The Open Court Publishing, 1963.

REDFIELD, R. Tepoztlan: A Mexican Village. Chicago: University of Chicago Press, 1930.

SCHMAUS, W. Durkheim's Philosophy of Science and the Sociology of Knowledge. Chicago: The University of Chicago Press, 1994. 
SCHUMPETER, J. Capitalism, Socialism and Democracy. Nova lorque: Harper and Row, 1950.

SOROKIN, P. A. Fads and Foibles in Modern Sociology and Related Sciences. Chicago: Henry Regnery Company, 1965.

WEBER, M. Economy and Society an Outline of Interpretive Sociology, Trad. de Ephraim Fischoff et alii, Berkeley: University of California Press, 1978.

WHITEHEAD, A. Adventures of Ideas. Nova lorque: The Free Press, 1961.

WORRAL, J. Is the Empirical Content of a Theory Dependent on its Rivals? In: NIINILUOTO; TUOMELA, R. (org.). The Logic and Epistemology of Scientific Change. Amsterdam: North-Holland Publishing, 1978.

\section{Endereço postal}

Largo de São Francisco, 1, Sala 325-A, Centro, Rio de Janeiro - RJ, 20051-070 